\title{
A Clog on the Right to Quality Education through OER: A Case of Japan and Malaysia
}

\author{
${ }^{1}$ Ratnaria Wahid, ${ }^{2}$ Khaliza Saidin \& ${ }^{3}$ Nurhaizal Azam Arif \\ ${ }^{1}$ School of International Studies, Universiti Utara Malaysia, Malaysia \\ ${ }^{2}$ School of Education and Modern Languages, Universiti Utara Malaysia, Malaysia \\ ${ }^{3}$ Faculty of International Studies, Hiroshima City University, Hiroshima, Japan \\ ${ }^{1}$ Corresponding author:ratnaria@uum.edu.my \\ DOI: https://doi.org/10.32890/jis2018.14.10
}

Received: 20 April 2018

Revised : 10 October 2018

Accepted: 12 December 2018

\begin{abstract}
States and world institutions have globally recognized the right to quality education. One of the method to access quality education is via Open Educational Resources (OER) that operates under the concept of "openness" where knowledge should be freely shared and disseminated for all. Yet, copyright law appears to be an area of great concern hampering OER development. This paper begins by clarifying the fundamental right to education which can be supported by developing trends of using digital resources. It then describes some of the developments in achieving sustainable development goal towards quality education through OER. The paper then explains certain legal challenges hampering open education initiatives by highlighting relevant copyright laws at the international and domestic levels. This investigation takes the form of a qualitative case-study approach comparing Malaysia and Japan practices in respect of its OER initiatives within their higher education institutions. This study specifically examines related regulations extracted from relevant statutes, cases, reports and secondary sources available in both countries. There appears to be a growing tension between the desire to promote open access to quality education and the need to protect works even though OER may be useful and beneficial for society.
\end{abstract}

Keywords: right to education, access, copyright law, OER, Japan, Malaysia

\section{Introduction}

Access to quality education is a dominant feature that has an indisputable direct link with economic and social development (Brende, 2015) but learning levels in many countries are highly unequal. One of the reason is due to unequal access to educational materials or the type of resources accessible for use (OECD 2012). High quality educational materials is often limited to those who can afford higher education or buying published materials.

A key issue is the legal framework that governs access to quality educational works online for the purpose of sharing knowledge. This is particularly relevant in the context of 
current Open Educational Resources (OER) initiatives that aspires freedom to retain, reuse, revise, remix and redistribute materials for the benefit of society. Accessing and utilizing educational works online is very much associated with increased risk of violating domestic and international copyright law. The risk of copyright infringement is a growing concern for academics, researchers, and educational institutions. "Access" here refers to not only the ability for users to obtain materials but also the liberty of users to utilize the materials as they wish. Users actually obtain limited rights to use these online works. It is not legal for users to simply reuse, remix or share the materials arbitrarily without prior permission from the right holder.

A considerable amount of literature has however raised the challenging aspect of giving knowledge for free (Hylén \& Schuller, 2007) specifically via OER. Research in OECD countries has found that copyright, together with sustainability issue, appear to be the two areas of great concern in OER development (Hylén, Damme, Mulder, \& D’Antoni, 2012). It has been observed that copyright law inhibits the smooth flow of open education initiatives around the world (Czerniewicz, Deacon, \& Walji, 2018; Ebner et al., 2017; Embi \& Alsagoff, 2013; McGreal, Anderson, \& Conrad, 2015; Walz \& Bekbalaeva, 2018; Yan, Au, Chan, \& Tsang, 2013; Yawan \& Ying, 2013).

Most research on OER were mainly held by European and North American countries (Zancanaro, Leomar Todesco, \& Ramos, 2015). Few studies have explored OER from diverse background particularly in non-English speaking communities relating to the challenges it faces with respect to copyright law. Cobo (2013) revealed that educators and learners from non-English speaking countries lack training, skills, technology infrastructures to be able to create and repurpose OER effectively which will cause deeper divide between those who can and cannot exploit OER. What remains unclear is how international and domestic copyright laws actually affect OER initiatives in different countries. This calls for a more concentrated study done in different continents in order to fully exploit the full potential of OER (Bentley \& Chib, 2016; King, Pegrum, \& Forsey, 2018).

Specific observation on certain countries like Japan for instance, generally publishes annual report on OER but has yet to conduct an extensive research on OER and its legal concerns. Although Kyoto University (2014) has conducted a survey on the use of OER and MOOCs, it has not specifically investigated the copyright management aspects which is important for sustaining OERs initiatives. To date, there has been little agreement on the role of law in supporting OER initiatives. A systematic understanding of how individual country's copyright law contributes to OER initiatives is still lacking. Previous studies has not been able to provide a robust strategy for supporting OERs using different alternatives although more support with interpreting copyright laws and/or securing copyright permission is requested (Yamada 2013).

In the pages that follow, it will be argued that despite world aspiration towards the right to quality education which may be achieved through OER initiatives, the limited flexibilities 
offered by law for the purpose of education are ineffective to support such noble aim. This paper begins by clarifying the fundamental right to education recognized by various nations which may be supported by developing trends towards using digital resources in education. It will then proceed to describe recent developments in achieving sustainable development goal towards quality education through OER. The paper then explains certain legal challenges facing OER initiatives by highlighting relevant copyright laws at the international and domestic levels. This investigation takes the form of a qualitative case-study approach comparing Japan and Malaysia OER policies and practices within their higher education institutions. This study make use of related regulations extracted from relevant statutes particularly copyright Acts of both countries, reports, journals and publications available in both countries. There appears to be a growing tension between the desire to promote open access to quality education and the need to protect works even though OER may be useful and beneficial for society.

\section{Fundamental Right to Education}

The right to education is a fundamental human rights to be universally protected and recognized by representatives from different legal and cultural backgrounds. The right to education is enumerated in Article 26(1) of the Universal Declaration of Human Rights as proclaimed by the United Nations General Assembly in 1948 which reads:

Everyone has the right to education. Education shall be free, at least in the elementary and fundamental stages. Elementary education shall be compulsory. Technical and professional education shall be made generally available and higher education shall be equally accessible to all on the basis of merit.

As the Universal Declaration is not a treaty, it is not legally binding on member countries, but pose as an expression of fundamental values shared by the international community. The right to education is now a common standard of achievements for all peoples and nations.

Article 13(1) of the International Covenant on Economic, Social and Cultural Rights (ICESCR), adopted by the United Nation General Assembly on 16 December 1966, also recognized everyone's right to education providing that:

The States Parties to the present Covenant recognize the right of everyone to education. They agree that education shall be directed to the full development of the human personality and the sense of its dignity, and shall strengthen the respect for human rights and fundamental freedoms. They further agree that education shall enable all persons to participate effectively in a free society, promote understanding, tolerance and friendship among all nations and all racial, ethnic or religious groups, and further the activities of the United Nations for the maintenance of peace. 
Article 13 thus provides a wide-ranging article on the right to education in international human rights law. Being a multilateral treaty, Article 13(2)(c) of the ICESCR has also made it an obligation for all member countries to make higher education equally accessible to all, on the basis of capacity, by every appropriate means, in particular by the progressive introduction of free education.

The general comment by the Committee on Economic, Social and Cultural Rights (1999) on the right to education noted the importance of such empowerment right which play a vital role in empowering women, safeguarding children from exploitation, promoting democracy as well as protecting environment. The same committee also noted that educational institutions and programmes should be accessible within the jurisdiction of the state party, without discrimination be it in the form of physical accessibility nor economic accessibility. This means that state parties should try their best to introduce free education.

The 2030 Agenda for Sustainable Development agreed by various Head of State under SDG 4 has further pledge towards ensuring inclusive and equitable quality education and promote lifelong learning opportunities for all. Through SDG 4, all UN member states are required to address all forms of exclusion and inequalities in access, participation and learning outcomes.

\section{The Rise of Digital Resources in Education}

Felicitous to the right to education, there has been increased emphasis on sharing of educational resources online as it has various benefits and advantages. Rapid technological development has largely improved the common way of obtaining or accessing contents for the purpose of education. Contents in digital format may be designed, updated, modified, transferred, and shared quickly and with little or no costs to those having internet access. Technology has invariably enhanced teaching in a way that it allows more data or information easily searchable, data sharing, tool to collect, analyze data. Digital format allows the ease of faster finding, wider reaching, more effective than traditional methods. The educational materials may be in the form of text, videos, audio, images, graphics created for the purpose of teaching or learning, disseminated through different medium such as lecture videos, animated videos, online courses, digital textbooks, digital images, lessons, activities or games. Educators nowadays do not have to just stick to the old textbooks but can choose from various lists of materials available digitally. These materials are sometimes uploaded in their learning management systems for students' use. Educators may also be part of the creators of digital contents so that their work may benefit others.

Several studies suggest that sharing educational resources via technology is fast becoming a key instrument in current educational system. More and more contents are being digitized including educational contents that may be processed by a computer or mobile phones. Studies revealed that $70 \%$ of reading time was spent on digital media despite the fact that 
more people prefer print media (Kurata, Ishita, Miyata, \& Minami, 2017; Parodi, Morenode-León, Julio, \& Burdiles, 2019). Studies indicated the increasing use of digital media in higher education and the rising demand for digitized contents (Rafiq \& Ameen, 2012). Contemporary teaching method may include e-learning, virtual and augmented reality, or networked based community learning accessible via digital devices like smartphones, laptops, computers or digital whiteboards (Molnar, 2015). This calls for more acquisition of information resources in digital formats and more digitizing of resources initiatives. Academic libraries at national and global levels are growing their collections of new forms of digital scholarship to improve access and to make contents widely available for users (Gwynn, Henry, \& Craft, 2019). Sharing data involved extensive labour and skills which sometimes goes unrewarded (Borgman, Scharnhorst, \& Golshan, 2019).

A growing body of literature that recognises the rising significance and dependency of digital educational materials. Scholars have come to rely on database that offers new means of discovering scholarly texts to read and cite (Bilansky, 2016). Materials can be obtained via pay-walled content, social channels like ResearchGate (Green, 2019) and web portal repositories (Leng, Ali, \& Hoo, 2016). Traditional print thesis and dissertations are being remediated electronically and encouraged to be made broadly accessible (Edminster \& Moxley, 2002). Increasing universities have offer repositories that provides persistent access, making content easily discoverable for anyone having internet access as an alternative to traditional publishing mechanism (Soehner, 2002).

Emerging trends of participation within higher education programs call for a huge demand for high-level educational resources that are available online both freely and openly. Access to resources via the internet also support the lifelong learning towards developing information society. Acquiring information that are readily accessible and can be shared, used and reused is powerful and may have great impact towards public good.

\section{Open Educational Resources}

One of the important measures to achieve SDG Goal 4 towards quality education is through the use of digital resources called Open Educational Resources (OER) (McGreal, 2017). OER has formed part of the central strategy for many education programmes including UNESCO. OER was recognized by UNESCO when the term was first used in the UNESCOhosted Forum on the Impact of Open Courseware for Higher Education in Developing Countries.

During the UNESCO Forum on Open Courseware, the term "OER" was defined as "the open provision of educational resources, enabled by information and communication technologies, for consultation, use and adaptation by a community of users for non-commercial purposes (2002, p. 24). The idea evolves from the recognition that knowledge as a social product and can become an international social property. Upon the conclusion of the UNESCO Forum 
in 2002, a universal educational resource available for the whole community is aimed to be together develop called Open Educational Resources. Alternatively, OER may also be called open courseware, open learning resources and open teaching or learning resources (UNESCO, 2002).

Over the years, UNESCO has been very supportive towards improving OER in higher education system. UNESCO has come out with publications, brochures, guidelines, surveys that may be used by governments, higher education institutions, academic staff, student bodies and quality assurance and recognition bodies (Butcher, 2015). UNESCO has also developed several documents such as action plan, study on international collaboration, reports and organize several conferences in relation to OER initiatives (UNESCO, 2018a). Ten years after the Forum, a Paris OER Declaration 2012 was established, mindfully taking into consideration other international statements. Under the OER Declaration, the World Open Educational Resources Congress calls upon governments worldwide to foster awareness and use of OER; facilitate enabling environments for use of ICT, reinforce the development of strategies and policies on OER, promote the understanding and use of open licensing frameworks, support capacity building for the sustainable development of quality learning materials, foster strategic alliances for OER, encourage the development and adaptation of OER in a variety of language's and cultural contexts, encourage research on OER, facilitate finding, retrieving and sharing of OER and encourage the open licensing of educational materials produced with public finds.

Since the 2012 Paris OER Declaration, studies showed an increasing support for OER policies at the national, institutional and project level (Commonwealth of Learning, 2017). Most OER activities are implemented through the initiative of institutions and engaged individual, or through specific programmes or projects funded by public (Commonwealth of Learning, 2017). The most popular reason for offering OER is to promote open and flexible learning opportunities and to increase efficacy and quality of learning resources(Commonwealth of Learning, 2017).

Universities around the world have started to invest on OER. This includes investing on developing the courses and materials, finding appropriate OER, adapting existing OER and negotiating copyright licensing, where necessary. Universities also have to bear associated costs for procuring and maintaining the ICT infrastructure. Such investment is to enrich the curriculum for students and to improve the quality of learning. (UNESCO \& Commonwealth of Learning, 2011). To date, OER materials can be found in various educational repositories and digital libraries, university and college websites, educational software and entertainment media websites, governmental websites, professional organizations' websites, and web search engines (Shank, 2014). Various open courseware initiatives such as Open Courseware Consortium, Open Educational Resources Commons, Carnegies Mellon Open Learning Initiative, Multimedia Educational Resource for Learning and Online Teaching (MERLOT), Commonwealth of Learning (COL) and Directory of Open Access Journals $(\mathrm{DOAJ})$ have been participating in joint international effort to achieve future sustainability of the open sharing of educational resources (Shank, 2014; Vladoiu, 2011). 


\section{Copyright Law and Access to Works for Educational Purposes}

Studies exploring OER practices in the UK, USA, Canada, South Korea, Japan and Turkey raised some copyright concerns and its effect to reproducibility (Keskin et al., 2017). Often, educational contents such as literary works and images are abundant on the internet but most are copyright restrictive.

Access to all literary works whether online or offline, are governed automatically by copyright law. Copyright law grants creators or owners of works (which can be the authors or publishers) the right holder, economic rights i.e the right to control their works from being copied, distributed, or adapted without their permission as well as moral rights which is the right to be attributed, that the works cannot be changed etc. The term of protection of copyright works varies depending on the national laws of individual countries and form of works but normally extends for a period of 50 to 70 years plus life of the right holder. The original purpose of copyright law as expressed in the early documents such as the UK Statute of Anne is mainly to provide incentives for authors so that authors would be encouraged to create more work for the benefit of society. The copyright system is governed by international treaties as well as domestic law of a country which may differ between one country to another.

Accessing and utilizing third parties works in traditional classroom method is not much of an issue in respect of its legal implication. Except for teaching compilations that may require some copyright clearance in order for it to be legally used, teachers or educators may rely on a variety of exceptions to copyright law when using third party materials in class. The situation however is different when accessing educational contents in online environment.

\section{a) International Provision}

The law relating to access and use of contents for the purpose of education may be referred to Article 10(2) of the Berne Convention for the Protection of Literary and Artistic Works 1971 (Berne Convention) which reads:

It shall be a matter for legislation in the countries of the Union, and for special agreements existing or to be concluded between them, to permit the utilization, to the extent justified by the purpose, of literary or artistic works by way of illustration in publications, broadcasts or sound or visual recordings for teaching, provided such utilization is compatible with fair practice.

Article 10(2) specifically permits utilizing copyright works for teaching subject to certain conditions such as justified by the purpose of works and compatible with fair practice. What is "fair practice" and "justified" is of subjective matter and ultimately depends on the decision of national courts of the country. Using works without permission or paying 
compensation or utilizing substantial amount of works as commonly practiced in OER, does not seem to fall under such criteria although its for teaching purposes since it may be inconsistent with common practices. Review on the teaching exceptions under Article 10(2) of the Berne Convention further excludes education taught outside the formal educational institutions. Nevertheless, this view proved to be disadvantageous especially in the setting where technology opens up opportunities for distance learning and lifelong learning.

These requirements under Article 10(2) of Berne Convention are also incorporated under Article 13 of the WTO Agreement on Trade-Related Aspects of Intellectual Property Rights 1994 (TRIPs) which binds all WTO member countries. Article 13 requires that member countries confine its exceptions to exclusive rights to a) certain special cases b) which do not conflict with a normal exploitation of the work and c) do not unreasonably prejudice the legitimate interests of the right holder. These requirements are meant to be as guidelines that needs to be followed by member countries. The real application of this guidelines operate only when there are specific regulations provided in the local laws of a country.

\section{b) Domestic Application: Japan and Malaysia}

A further look into the domestic law of a country may draw our understanding on the challenges that copyright law brings to OER initiatives. Malaysia and Japan are selected as a case study to represent Asian experience on the issue. Japan is chosen as it is considered as one of the leading nations in respect of educational achievements. Malaysia is picked for comparative purposes as the Malaysian Prime Minister Tun Dr. Mahathir Mohamad has encouraged Malaysia to remain with its Look East Policy in cooperation with Japan to further empower the national education system (Bernama, 2018).

Japan, containing of approximately 126 millions of people is known for its high-standard copyright law and enforcement. Japan, being an intellectual property-based nation, is increasingly acting as an exporter of IP and thus emphasizing on greater protection of intellectual property (IP) rights (Katoh, 2002). The Copyright Amendment 2012 has further strengthen and extend its copyright protection from 50 years term to 70 years. Japan is also the third highest country that file patent applications in the world after China and the US. In 2017, Japan IP office received 318,479 patent applications while Malaysia only receive 7,072 patent applications (WIPO, 2018). This stark contrast clearly shows that intellectual property laws is of great importance to Japan since it manage the vibrant IP activities. Japanese IP law is fully in compliance to the standards of internationally recognized rules, that responds to the developments of digital technology and the emergence of internet. Case law further provides broader protection of copyright law in Japan, compared to other countries. Attempts to reform copyright law that promotes distribution of digitized contents were not well supported nor positively responded (Kozuka, 2013).

Comparatively, Malaysia, a middle income country with a population of approximately 31.62 million people is mostly users of IP works. Copyright protection in Malaysia is 
governed under the Copyright Act 1987 (latest amendment in 2012). Malaysia is a signatory to the Berne Convention and also a party to the WTO TRIPs Agreement. Malaysia has previously been alleged as exporters of pirated products. Various anti-piracy effort has however been taken including toughening its domestic laws. Malaysia has also been engaging with other countries through several trade agreements, with regard to adequate and effective IP protection and enforcement (USTR, 2018).

In terms of budget allocation, Malaysia spends $21.1 \%$ of its total government expenditure on education in 2017 which is more compared to Japan which only spends $9.1 \%$ in 2016 (UNESCO, 2018b). In 2017 Japan spent around 5.7 trilllion yen on education and science (Statista, 2018) while Malaysia allocated a sizeable 61.6 billion ringgit for education sector (Adnan, 2017).

As regards to OER development, Japan is considered as "innovators" nation (Rogers, 1962) and early adopters of OER initiatives in Asia (Yamada, 2013). In 2004, Japan Open Courseware Consortium (JOCW) (a consortium of Japanese Universities) has been providing open courseware $(\mathrm{OCW})$. The Japan Open Education Consortium was established through a concerted cooperation between leading universities for the purpose of benefiting educational communities through sharing know how and intellectual assets while preserving the originality and autonomy of participating university(JOCW, 2006). Through OCW, free publication of formal course materials of higher educational organizations like teaching modules from different subjects are made available over the internet and may be reused and downloaded to almost any mobile device (Vladoiu, 2011). To date, the number of course materials available online provided by Japanese institutions has been growing and the number of visits to JOCW has also increased. This is despite the fact that open textbooks are already affordable and that Japanese institutions are self-sustainable in terms of open education activities, operating without government or foundations support (Shigeta et al., 2017).

In contrast, OER is regarded as a relatively new phenomenon in the Malaysian higher education sector which desires for much institutional support and recognition (Abeywardena, Dhanarajan, \& Lim, 2013). Studies showed that the main sources of OER in Malaysia are produced by academics within the institution, or freely downloaded from the internet and coming from co-operation with other institutions (Abeywardena et al., 2013; Embi \& Alsagoff, 2013). Most OER is produced as learning objects or as part/full courses and programmes but there is lack of cooperation when producing and exchanging OER among educational institutions.

Previous studies conducted in both Japan and Malaysia, revealed serious concern over copyright infringement when publishing and using digital resources (Abeywardena et al., 2013; Shigeta et al., 2017). Difficulties arise in interpreting copyright laws such as clarifying fair use or fair dealing for educational use and clearing copyright are one of the most important technical barriers when using digital resources (G. Dhanarajan \& Abeywardena, 
2013). Even though academics have been exposed to open content licenses, there was still a degree of fear with respect to using material licensed in this manner. This is due to lack of in-depth knowledge of copyright legislation and different alternatives available beyond copyrighted materials such as Creative Commons licensing. Thus, comprehensive knowledge of copyright plays a crucial role in encouraging academics to engage in OERrelated activities.

Malaysian Copyright Act, for example allows "the inclusion" of works for teaching which is very narrow in interpretation as it does not include sharing nor reproduction (Wahid \& Azmi, 2012), which is considered important in materializing OER. Comparatively, Japan under Article 35 of its Copyright Act permits educators and learners to reproduce copyright works as long as it does not unreasonably prejudice the interests of the copyright owner in light of the nature, purpose as well as the number of copies and the form of reproduction. These shows some legal impediments attached upon the successful realization of OER.

In addition, several countries' copyright law allow a general fair use or fair dealing exception. Section 13(2)(a) of the Malaysian Copyright Act 1987 for instance permits using copyright works for research or private study purposes by way of fair dealing. What amounts to fair dealing must however be subject to different tests where only the courts will have the final say on what is fair. Teaching in the digital world could include students from all parts of the world and not limited to a certain number of students in a specific location, it is thus unlikely that fair dealing applies to OER context. Hence, copyright clearance is necessary if the contents are not in the public domain or under open license. Japan on the other hand, did not have any fair dealing or fair use exceptions but specifically expressed the limitation of the copyright law from Article 30 to 49 of its Copyright Act. Considering all these requirements in copyright exceptions, it leaves user with limited flexibilities to use works for educational purposes.

In practice, instructors using third party's works the course materials used in OER need to obtain rightholders' approval before using such works. So, each of the materials provided for OCW goes through a copyright clearance process and students are trained for copyright clearances whenever they are involved with content creation. Osaka University for instance, specified the problem of time consuming to specify the author of works and difficulties in obtaining approval from publishing companies (JOCW, 2006). Hence, in most cases, the instructors will need to produce the content themselves with a few support from technical staff that mainly helps with copyright clearance, translation and registration on the server (JOCW, 2006). Another practice is through outsourcing rather than using own facility when dealing with contents that requires images and high technical skills (JOCW, 2006). This is due to scarce funding and the challenge of making sophisticated high quality materials. Content production is more of a top down institutionalized form using internal university budget rather than grass-root activity (JOCW, 2006).

To avoid copyright clearance obstacles, OER creators usually resort to open licences, (normally Creative Commons), as well as attribution to authors. This is generally the case in 
Malaysia where support in terms of funding and human resources are limited. However, not many people are aware as to which works are under open licenses which permits retaining, reusing, revising, remixing, redistributing. Common perception is that any works available online is in public domain, and thus may be reuse or shared, which is totally misunderstood.

\section{c) Legal Risks and Impact to OER}

Despite several flexibilities made available by international law to permit the use of copyrighted works for the purpose of education, it hardly applies in the context of online teaching and learning particularly OER. Careful analysis of the copyright exceptions, shows that it is very unlikely that educators can use digital works under these exceptions. This means that educators must ensure that every works used must be free from copyright violations. This leaves the educators with the risk of copyright infringement if they reuse the digital materials or share it with their students. Accessing and using digital materials owned by third party may thus lead users to a myriad of copyright related issues. Infringing copyright law would cause serious repercussion, largely in terms of financial and reputation.

Clearing copyright may involve investment of time, money, energy. Gadd (2001) revealed that rights clearance prove to be complicated, time consuming requiring a minimum of ten distinct steps and requiring manpower to execute. Painstaking effort is needed to obtain permission or getting copyright clearance to use third party's works for teaching. Reasons for control of data is because of the sense of ownership and protecting privacy, due to extensive labour involved in documenting data (Borgman et al., 2019). The decision to share or not to share educational contents with community also depends on who owns the contents, whether it's the author, group of authors, educational institutions, publisher,. Copyright owner has the power to decide how the rights are to be licensed and enforced. In addition, users need to face paywalls to access journals with exorbitant subscription fees that further limit the ways to use scholarly articles. Hence copyright law can either became an impediment of knowledge dissemination and creation (Guibault, 2011).

More and more institutions are realizing the potential of OER and started to develop policies with regard to contents in the public domain (Keskin et al., 2017). In a way, copyright challenges may become a stepping stone for people to be more aware of their service to others. Some may argue that open licenses is already available to address this panacea. Nevertheless, it is important to remember that copyright protection is automatic while opting for open licenses is a choice that may only be made by those with proper knowledge. This puts freely available works under open licenses as mere mass of splinters or just a small patch in the big picture.

\section{Discussion}

All people are entitled to the right to education and to receive and impart information through any media regardless of frontiers. The 2030 Sustainable Development Agenda, particularly 
Goal 4 requires that all international community ensure an inclusive and equitable quality education and to promote lifelong opportunities for all. The 2009 World Conference on Higher Education Communique also emphasized the importance of widening access to quality education which can be achieved through sharing of OER among countries. OER brings potential to meet at least some of the growing demand for education in the $21^{\text {st }}$ century (King et al., 2018) by becoming the solution to provide students around the world with access to quality learning materials. OER is a place where people can share their works, build upon works of others, and disseminate information and knowledge for the benefit of society. Such potential should not be taken lightly and left to chances. It should have clear strategies, overwhelming supports, and thoughtful directions.

Universities and research institutions are commonly pressured to create and accumulate more IP; to facilitate commercialization of government funded research, and to be proactive in managing IP developed on campus (Katoh, 2002). The present concept of commodification of knowledge and IP ownership which will get academics tenureship and promotion somehow evacuate the idea of academic freedom and collegiality (Downing, 2005). Research shows that many universities claim ownership on e-learning materials compared to internal teaching materials (Gadd \& Weedon, 2017). Moreover, large scientific publishing houses also control academic works, thereby increasing costs, reduce researchers negotiating power and hamper technical and scientific developments (Hylén, 2005).

The monopolizing practices may invariably restrict inquiry, learning, imagination and interaction in teaching or research. This is inconsistent with the 2003 World Summit on the Information Society, Declaration of Principles, which commits to build a people-centred, inclusive and development-oriented Information Society where everyone can create, access, utilize and share information and knowledge. Similarly, it also strife against the 2005 UNESCO Convention on the Protection and Promotion of the Diversity of Cultural Expression, which considers equitable access to a rich and diversified range of cultural expressions and dissemination constitute as important elements for enhancing cultural diversity and encouraging mutual understanding.

Much of OER activities are based on a voluntary basis at regional, national or institutional level. It also depends very much on the level of interest, capacity and resources available. Numerous activities done to raise awareness and capacity building on OER has not been able to meet the challenges emerging from the Education 2030 Framework for Action, as well as Goal 4 of the SDG Agenda (UNESCO, 2017). Hence, there is a need for specific legal framework related to the area of educational content and its licensing that would be useful to encourage national policy formulation and the use of OER at all levels (UNESCO, 2017).

Although technology has made things faster, cheaper, easier and nearer the technical challenges posed by copyright system has somewhat hackled the opportunity that technology brings. Copyright regulation has created more hassle, time and risk to the extent that people may be deterred from using useful works to create OER that can benefit others. Current 
exceptions to copyright law in both international treaties and local laws do not support the application of teaching and learning in digital context. Educators are left with the risk of infringing the law which could lead to negative financial and reputation.

This study recommends that higher educational institutions work together with academic staff to address copyright issues and encourage OER initiatives. It is also useful for policy makers to consider limiting copyright law rather than enhancing it more and more. Government may play an important role in regulating the behaviours of content creators by using soft power to encourage voluntary actions of freeing information. Future studies may further investigate why individuals and institutions engaged in OER. Specifically, what makes people share or give away their work for free?

OER can preserve traditional academic values that has been increasingly marginalized by market forces. Free sharing would provide broader and faster dissemination of works, creating rapid technical and scientific development, reinforce societal development and reduce social inequality (Hylén, 2005). It is of academic community virtues to pursue academic freedom and collaboration or collegiality in order to pursue truth and knowledge (Liang, 2018). There is much need for more contents to be available in the public domain, containing Creative Commons attributes, or permission granted by copyright holder and the law should not become a barrier to access quality resources.

\section{Conclusion}

This paper sets out to explain the importance of right to education and accessing quality education as inspired by international treaties and encouraged by international bodies. This empowerment right is even essential in the changing trends of using digital works in educational settings. One of the alternative to address access to quality education is through OER initiatives. Through OER, countries and institutions have taken several efforts to open access to information or free knowledge. Nonetheless, there are growing concern that international copyright law and local legislation actually hamper access and use of work in OER environment. Flexibilities provided under the law does not seem to be applicable in OER situation, thereby opening up the risk of copyright infringement for educators. After analysing the laws and practices of individual country, this study has shown that the present copyright system has hackled the opportunity that technology brings to free information. Over the years, copyright law is being strengthened more and more through bilateral and multilateral treaties around the world, lobbied by interested parties. Future trends will see more use of technology, artificial intelligence, big data that requires more data sharing and sharing of information. Hence, information should not be left in the hands of only certain group of people or institutions, but should be shared by the community. While it is difficult to suggest for total reform to copyright legal system to suit the digital environment, more discussion should be done to address such matters. What remains important is to utilize innovation and collaboration between government, private sector and civil-society organizations to improve the quality of education. 


\section{Acknowledgement}

This research was supported by The Sumitomo Foundation Fiscal 2017 Grant for JapanRelated Research Projects No. 178430.

\section{References}

Abeywardena, I. S., Dhanarajan, G., \& Lim, C. K. (2013). Open Educational Resources in Malaysia. In Gajaraj Dhanarajan, \& D. Porter (Eds.), Open Educational Resources: An Asian Perspective (pp. 121-134). Vancouver: Commonwealth of Learning.

Adnan, A. S. (2017). 2018 Budget: Sizeable allocation for Education shows government's commitment. Retrieved May 14, 2019, from https://www.nst.com.my/news/ nation/2017/10/296075/2018-budget-sizeable-allocation-education-showsgovernments-commitment

Bentley, C. M., \& Chib, A. (2016). The Impact of open development initiatives in lower- and middle income countries: A review of the literature. The Electronic Journal of Information Systems in Developing Countries, 74(1), 1-20. https://doi. org/10.1002/j.1681-4835.2016.tb00540.x

Bernama. (2018). Look East policy to the fore again, more cooperation from Japan in education sought. Retrieved from https:/www.nst.com.my/news/nation/2018/11/428760/lookeast-policy-fore-again-more-cooperation-japan-education-sought

Bilansky, A. (2016). Search, reading, and the rise of database. Digital Scholarship in the Humanities, 32(3), 511-527. https://doi.org/10.1093/llc/fqw023

Borgman, C. L., Scharnhorst, A., \& Golshan, M. S. (2019). Digital data archives as knowledge infrastructures: Mediating data sharing and reuse. Journal of the Association for Information Science and Technology, 00(0), 1-17. https://doi.org/10.1002/asi.24172

Brende, B. (2015). Why education is the key to development. Retrieved from https://www. weforum.org/agenda/2015/07/why-education-is-the-key-to-development/

Butcher, N. (2015). A basic guide to Open Educational Resources (OER). (S. UvalicTrumbic \& A. Kanwar, Eds.). Vancouver: Commonwealth of Learning \& UNESCO. Retrieved from http://oasis.col.org/bitstream/handle/11599/36/2015_UNESCO_ COL_A-Basic-Guide-to-OER.pdf?sequence $=6 \&$ isAllowed $=y$

Cobo, C. (2013). Exploration of open educational resources in non-english speaking communities. International Review of Research in Open and Distance Learning, 14(2), 106-128. https://doi.org/10.19173/irrodl.v14i2.1493

Commonwealth of Learning. (2017). Open Educational Resources: Global Report 2017. Burnaby. Retrieved from http://oasis.col.org/bitstream/handle/11599/2788/2017_ COL_OER-Global-Report.pdf?sequence=1\&isAllowed $=\mathrm{y}$

Czerniewicz, L., Deacon, A., \& Walji, S. (2018). Educators, copyright and Open Education Resources in massive open online courses. In M. Bajic, N. Dohn, M. De Laat, P. Jandric, \& T. Ryberg (Eds.), Proceedings of the 11th International Conference on Networked Learning (pp. 264-271). Retrieved from https://idl-bnc-idrc.dspacedirect. org/bitstream/handle/10625/57087/57145.pdf?sequence=1\&isAllowed=y 
Dhanarajan, G., \& Abeywardena, I. S. (2013). Higher education and open educational resources in Asia: An overview. In G. Dhanarajan \& D. Porter(Eds.), Open Educational Resources: An Asian Perspective (pp. 3-20). British Columbia: Commonwealth of Learning and OER Asia.

Downing, D. (2005). Academic freedom as intellectual property: When collegiality confronts the standardization movement. Symploke, 13(1), 56-79. https://doi.org/10.1353/ sym.2006.0015

Ebner, M., Lorenz, A., Lackner, E., Kopp, M., Kumar, S., Schön, S., \& Wittke, A. (2017). How OER enhances MOOCs-A perspective from German-speaking Europe. In M. Jemni \& M. K. K. Kinshuk (Eds.), Open Education: from OERs to MOOCs. Lecture Notes in Educational Technology (pp. 205-220). Berlin, Heidelberg: Springer. https://doi.org/10.1007/978-3-662-52925-6_11

Edminster, J., \& Moxley, J. (2002). Graduate education and the evolving genre of electronic theses and dissertations. Computers and Composition, 19(1), 89-104. https://doi. org/10.1016/S8755-4615(02)00082-8

Embi, M. A., \& Alsagoff, Z. A. (2013). Finding, creating and sharing OER. In M. A. Embi (Ed.), Open Educational Resources in Malaysian Higher Learning Institutions (pp. 19-31). Selangor: Universiti Kebangsaan Malaysia and Ministry of Higher Education.

Gadd, E. (2001). An examination of the copyright clearance activities in UK Higher Education. Journal of Librarianship and Information Science, 33(3), 112-125. https://doi.org/10.1177/096100060103300302

Gadd, E., \& Weedon, R. (2017). Copyright ownership of e-learning and teaching materials: Policy approaches taken by UK universities. Education and Information Technologies, 22(6), 3231-3250. https://doi.org/10.1007/s10639-017-9583-4

Green, T. (2019). Is open access affordable? Why current models do not work and why we need internet-era transformation of scholarly communications. Learned Publishing, 32(1), 13-25. https://doi.org/10.1002/leap.1219

Guibault, L. (2011). Owning the right to open up access to scientific publications. In L. Guibalt \& C. Angelopoulos (Eds.), Open content licensing : from theory to practice (pp. 137-167). Amsterdam: Amsterdam University Press. https://doi. org/10.5117/9789089643070

Gwynn, D., Henry, T., \& Craft, A. R. (2019). Collection creation as collection management: libraries as publishers and implications for collection development. Collection Management, 1-15. https://doi.org/10.1080/01462679.2019.1579012

Hylén, J. (2005). Open Educational Resources : Opportunities and challenges. Retrieved from http://www.oecd.org/education/ceri/37351085.pdf

Hylén, J., Damme, D. V, Mulder, F., \& D’Antoni, S. (2012). Open Educational Resources: Analysis of responses to the OECD country questionnaire (OECD Education Working Papers No. 76). OECD Publishing. https://doi.org/10.1787/5k990rjhvtlv-en

Hylén, J., \& Schuller, T. (2007). Giving knowledge for free. OECD Observer. https://doi. org/10.1787/9789264032125-en 
JOCW. (2006). A Case Study in Open Educational Resources Production and Use in Higher Education. Tokyo. Retrieved from http://www.oecd.org/education/ceri/37647892. pdf

Katoh, M. (2002). Intellectual Property and the Internet: A Japanese Perspective. Journal of Law, Technology and Policy, 333-360.

Keskin, N. Ö., Koutropoulos, A., de Waard, I., Metcalf, D., Gallagher, M., Anzai, Y., \& Buyuk, K. (2017). National Strategies for OER and MOOCs From 2010 to 2020. In Administrative Leadership in Open and Distance Learning Programs (pp. 188-212). IGI Global. https://doi.org/10.4018/978-1-5225-2645-2.ch008

King, M., Pegrum, M., \& Forsey, M. (2018). MOOCs and OER in the Global South: Problems and Potential. The International Review of Research in Open and Distributed Learning, 19(5). https://doi.org/10.19173/irrodl.v19i5.3742

Kozuka, S. (2013). Reforming Japanese Copyright and Content Disribution Laws: The Commodification of "Cool Japan"? SSRN ELibrary, 1-16. Retrieved from https:// papers.ssrn.com/sol3/papers.cfm?abstract_id=1912199

Kurata, K., Ishita, E., Miyata, Y., \& Minami, Y. (2017). Print or digital? Reading behavior and preferences in Japan. Journal of the Association for Information Science and Technology, 68(4), 884-894. https://doi.org/10.1002/asi.23712

Leng, C. B., Ali, K. M., \& Hoo, C. E. (2016). Open access repositories on open educational resources. Asian Association of Open Universities Journal, 11(1), 35-49. https://doi. org/10.1108/AAOUJ-06-2016-0005

Liang, L. (2018). Academic Freedom and the Ownership of Knowledge. In D. Bhattacharya (Ed.), The University Unthought : Notes for a Future (pp. 163-182). Delhi: Taylor \& Francis.

McGreal, R. (2017). Special Report on the Role of Open Educational Resources in Supporting the Sustainable Development Goal 4: Quality Education Challenges and Opportunities. International Review of Research in Open and Distributed Learning, 18(7). https://doi.org/https://doi.org/10.19173/irrodl.v18i7.3541

McGreal, R., Anderson, T., \& Conrad, D. (2015). Open Educational Resources in Canada 2015. International Review of Research in Open and Distributed Learning, 16(5), 161-175. https://doi.org/https://doi.org/10.19173/irrodl.v16i5.2404

Molnar, G. (2015). Teaching and learning in modern digital environment. In 2015 IEEE 13th International Symposium on Applied Machine Intelligence and Informatics (SAMI) (pp. 213-217). IEEE. https://doi.org/10.1109/SAMI.2015.7061878

Parodi, G., Moreno-de-León, T., Julio, C., \& Burdiles, G. (2019). Google or Gutenberg Generation: Chilean university students' reading habits and reading purposes. Comunicar, 27(58), 85-94. https://doi.org/10.3916/C58-2019-08

Rafiq, M., \& Ameen, K. (2012). Use of digital media and demand for digitized contents in higher education sector of Pakistan. SciVerse ScienceDirect, 44, 116-122. https:// doi.org/10.1016/j.iilr.2012.04.007

Rogers, E. M. (1962). Diffusion of Innovations (Third Edition). New York: The Free Press. Retrieved from https://teddykw2.files.wordpress.com/2012/07/everett-m-rogersdiffusion-of-innovations.pdf 
Shank, J. D. (2014). Interactive open educational resources: A guide to finding, choosing, and using what's out there to transform college teaching. San Francisco: Jossey Bass.

Shigeta, K., Koizumi, M., Sakai, H., Tsuji, Y., Inaba, R., \& Hiraoka, N. (2017). A survey of the awareness, offering, and adoption of OERs and MOOCs in Japan. Open Praxis, 9(2), 195. https://doi.org/10.5944/openpraxis.9.2.568

Soehner, C. B. (2002). The eScholarship Repository. Science \& Technology Libraries, 22(34), 29-37. https://doi.org/10.1300/J122v22n03_04

Statista. (2018). Japan: general account education spending 2018. Retrieved May 14, 2019, from https://www.statista.com/statistics/630230/japan-general-account-budget-educationscience-expenditures/

UNESCO. (2002). Forum on the Impact of Open Courseware for Higher Education in Developing Countries. Paris. Retrieved from https://unesdoc.unesco.org/ark:/48223/ pf0000128515

UNESCO. (2017). International Collaboration on Open Educational Resources (OER). Paris. Retrieved from https://unesdoc.unesco.org/ark:/48223/pf0000247751

UNESCO. (2018a). Open Educational Resources (OER): Resources. Retrieved May 14, 2019, from https://en.unesco.org/oer/resources

UNESCO. (2018b). SDG 4 Country Profiles - Technical Cooperation Group on the Indicators for SDG 4. Retrieved May 13, 2019, from http://tcg.uis.unesco.org/country-profile/

UNESCO \& Commonwealth of Learning. (2011). Open Educational Resources (OER) in Higher Education, 21. https://doi.org/http://dx.doi.org/10.1007/s12599-012-0219-3

USTR. (2018). 2018 Special 301 Report. Retrieved from https://ustr.gov/sites/default/files/ files/Press/Reports/2018 Special 301.pdf

Vladoiu, M. (2011). Open courseware initiatives - After 10 years. Proceedings - RoEduNet IEEE International Conference. https://doi.org/10.1109/RoEduNet.2011.5993712

Wahid, R., \& Azmi, I. M. (2012). Comparative study on copyright exception for teaching purposes: Australia, Malaysia and the United Kingdom. Journal of International Studies, 8, 31-45. Retrieved from http://jis.uum.edu.my/images/ pdf/8jis/3comparativestuudyy.pdf

Walz, A. R., \& Bekbalaeva, J. (2018). Assessing the Potential Toward Open Educational Practices in Kyrgyzstan. Open Praxis, 10(2), 159. https://doi.org/10.5944/ openpraxis.10.2.834

WIPO. (2018). WIPO IP Facts and Figures. Geneva: World Intellectual Property Organization. Retrieved from https://www.wipo.int/edocs/pubdocs/en/wipo_ pub_943_2018.pdf

Yamada, T. (2013). Open Educational Resources in Japan. In G. Dhanarajan \& D. Porter (Eds.), Open Educational Resources: An Asian Perspective (pp. 87-108). Vancouver: Commonwealth of Learning and OER Asia.

Yan, K., Au, M., Chan, R., \& Tsang, C. (2013). Open Education: Challenges in Hong Kong. In J. Lam, K. C. Li, S. K. S. Cheung, \& F. L. Wang (Eds.), Knowledge Sharing through Technology. ICT 2013, Communications in Computer and Information Science, vol 407 (pp. 212-226). Berlin, Heidelberg: Springer. https://doi.org/10.1007/978-3-64245272-7_20 
Yawan, L., \& Ying, L. (2013). A Study on the Use of Open Educational Resources in China. In Gajaraj Dhanarajan \& D. Porter (Eds.), Open Educational Resources: An Asian Perspective (pp. 21-39). Vancouver: Commonwealth of Learning and OER Asia. Retrieved from https://oerknowledgecloud.org/sites/oerknowledgecloud.org/files/ pub_PS_OER_Asia_web.pdf

Zancanaro, P. A., Leomar Todesco, J., \& Ramos, F. (2015). A Bibliometric Mapping of Open Educational Resources. International Review of Research in Open and Distributed Learning (Vol. 16). Retrieved from https://webofknowledge.com/ 